\title{
The Performance of Textile Companies in the North West Zone of Nigeria: the Role of Infrastructure as a Resource
}

\author{
GADO, N.D. \\ Faculty of Humanities, Social and Management Sciences, Bingham University, Karu \\ E.mail: nuhugado@yahoo.com
}

Nmadu, T.M. (Ph.D)

Department of Management Sciences, University of Jos, Jos

E.mail: nmadutm@yahoo.co.uk

Accepted: November 26, 2011 Published: January 9, 2012

doi:10.5296/ijhrs.v2i1.1259 URL: http://dx.doi.org/10.5296/ijhrs.v2i1.1259

\begin{abstract}
Textile companies in Nigeria have complained of stifling competition against the backdrop of challenges of declining endogenous and exogenous resources. Using electricity and capacity utilization as proxies, we show that electricity supply is a significant determinant of performance. We recommend, among others, that Public electricity supply to the textile companies should be taken as a state of emergency to ensure that there is uninterrupted power supply. Government at various levels should embark on intensive advocacy for Nigerians to develop a culture of using locally made goods while leading by example. Opinion molding should be employed both in the public and private sectors.
\end{abstract}

\section{Introduction}

Industries in Nigeria have long been crying of unfair competition from foreign products that find their way into the country through unauthorized means. Apart from lower cost of production from the countries of origin, these products come in duty free which allow the importers to sell at prices far lower than locally made goods. When combined with the preference of foreign products over locally manufactured goods, the unfair competition is 
compounded.

The Nigerian manufacturing sector has witnessed declining capacity utilisation resulting in reduced labour force (Obadan, 1998). The textile industry, a major player in manufacturing, appears to be on the fore front of this decline with reports of textile companies closing down on a yearly basis (Obadan, 1998; Jibrin, 2002). Amongst the complaints of the companies are the issues of electricity supply and smuggling of finished products. How central is power supply, as a resource, to the seeming disadvantaged position of local manufacturers in Nigeria? This, among others, is the issue this research paper has examined. This is done, bearing in mind, the multi-variability of factors that account for the performance of manufacturing companies, the textile companies not exempted.

\section{Review Of Literature}

The story of the Nigerian Textile Industry started with the establishment of the Kaduna mills in 1956. This was followed by the incorporation of the United Nigerian Textiles Limited in 1964. The third textile Company, Arewa textiles, came on stream in 1965. Towards the end of the 1960s other Companies like Afprint, Enpee, Asaba Textiles, Aswani Textiles and Five Star, joined the trail (Mohammed, 1984; Abubakar, 1997; Muhammed, 2003; and Uzoigwe, 2005). Between 1970 and 1987, the Nigerian Textile Industry prospered with demand for products far in excess of supply by 91 percent (Adebisi, 1987). During this period, the industry had more than 100 textile companies, employing over 200,000 workers. By this, the industry ranked second only after the Nigerian Government as an employer of Labour. By 1994, a total about of 124 textile companies were in operation in Nigeria (Uzoigwe, 2005).

In 1995, the textile companies began to experience problems with about 50 companies closing down in 1997 (Ahiuma-Young, 2003). As at 2004, quite a number of textile companies had folded. The Kaduna Textile Mills closed in 2002 while Enpee shut down operation in 2004. The United Textiles PLC (UNTL) that was regarded as the biggest Textile Company in West Africa with a direct work force of about 5,500 employees shut down its factory in Kaduna in October 2007, leaving about 4,400 abled workers unemployed.

Many reasons have been adduced for closure of textile industries. Aremu (2005) for example, opines that massive importation coupled with high cost of production resulted in the closing down of 65 local textile mills, rendering about 150,000 workers jobless. He almost concluded that the sector had collapsed with unpalatable implications to the nation by way of unemployment, poverty and social vices. Earlier, Ati (1985) and Ubani (1983) identified some performance limiting factors in the Nigerian business environment amongst which are: - problems of raw materials and equipment importation, inter-organizational relations, Governmental and parent - organization regulation and interference, indiscriminate importation and smuggling, and inadequate capital and skilled labour. Empirical studies have shown that infrastructural growth corresponds to economic output (CBN, 2000). Researches have further shown that poor infrastructures have hampered the progress of textile companies in Nigeria, making companies to provide their own power a situation Obadan (1998) refers to as BOYI meaning 'Build 
Your Own Infrastructure (David, 2003; Jibrin, 2002; Obadan, 1998; Ayodele, 1998). A look at the statistics of electricity supply to the industrial sector showed a steady decline in the megawatts of electricity. This shows a correlation with the declining performance of the textile sector. Several other reasons have been advanced for the fast and continuous decline of the Nigerian Textile Industry. Amongst the reasons advanced are:

1. Shortage of raw materials;

2. Competition from foreign Textiles occasioned by smuggling;

3. Deteriorating Machinery;

4. Falling demand, and

5. "Lack of management initiatives, resourcefulness and foresight" (Mohammed, 1984:1)

A negative consequence of the declining performance of the textile sector is the loss in Government revenue. It is estimated that over $\$ 3$ billion in revenue accruing to Federal, State and local Government by way of taxes and levies from textile operation is lost (Jibrin, 2002).

Industrialization and economic development usually co-exist. The Textile industry is usually regarded as a first generation industry in the process of industrialization. The textile production index $(1985=100)$ has fallen from 159.3 in 1992 to 98.6 in 1996 (CBN Annual Report, 1996). When considered with the fact that the sector now employs a paltry figure of 28,000 workers from an employment rate of 285,000 staff (Fanimo; Sanyaolu, and Akhaine, 2007), the present state of our Nation needs repositioning.

Ayodele (1998) described the public electricity situation in Nigeria as 'Energy Crisis'. Power supply, particularly electricity and petroleum, are crucial to the operation of the textile Companies. In Ayodele's words:

"outputs of the energy sector (electricity and petroleum products) usually consolidate the activities of other sectors which provide essential services to direct production activities of agriculture, manufacturing, mining, commerce, etc" (Ayodele, 1998:19).

The crisis power situation of the textile Companies is characterized by a consistent decline in the rate of public electricity supply to the industrial sector compared to the supply for residential use. This is evidenced by the break down of the total electricity supply to the Country. While, going by the CBN Statistical Bulletin (2007), the proportion going to residential users continues to rise (53.6\% in 1989 to $63.8 \%$ in 2005), the portion going to the Industries keeps on declining (28.4\% in 1989 to $18 \%$ in 2008). This is against the background of declining total electricity supply of 6,180.9 megawatts per hour in 2003 to 2,108 megawatts per hour in 2008 (Power holding company of Nigeria).

For all firms employing more than 50 employees, an average investment of 130,000 USD was made to generate private electricity for production. This contributed to increased production costs and consequent high product prices which made it difficult for such organizations to compete favourably in the international market (World Bank Report, 1991).

Sixteen textile companies, employing slightly over 7,000 workers, were operating in the North-West zone of Nigeria as at December, 2007 (National Union of Textile Garments Trade Union of Nigeria (NUTGTWN), 2007). As at December, 2008, only 7 of the 16 companies were still operating. This paper seeks to analyse the role of infrastructure, with 
particular reference to public electricity supply, on the performance of textile companies in the North-West zone of Nigeria.

\section{Research Methodology}

The objective of this paper is to analyse the association between the performance of the textile companies in the North-West zone of Nigeria, using Capacity Utilisation as a proxy, and resources, employing Public electricity supply as a critical resource measure. Our single hypothesis, stated in the null form, is that there is no significant correlation between resources (Public electricity supply) and performance (Capacity utilisation). The level of significance shall be determined at $95 \%$ confidence level, giving us a margin of error of $5 \%$. When split into a two tail test, this gives us an error level of $2.5 \%$. This level of significance is chosen because the results, while reducing the sample size (compared to 99\% confidence level), are considered significant enough for valid conclusions. Ninety percent (90\%) Confidence level was not used because it is considered only fairly significant (Lewis, 2000; Boreistein, 2005).

Our research was a scientific survey involving cross-sectional and longitudinal analysis (Asika, 2000; Frankfort-Nachmias and Nachmias, 1996). We sought to explore, describe, and explain the interplay of resources (Public electricity supply) and performance (Capacity utilisation) in the textile industry in the North-West zone of Nigeria amidst macro-environmental variables like inflation and cost of capital.

Secondary data of dependent variable (Capacity Utilisation) and independent variable (Electricity Supply) were obtained from documented annual reports from the Central bank of Nigeria (CBN), the Power Holding Company of Nigeria (PHCN), and the National Union of Textile Garments and Tailoring Workers of Nigeria (NUTGTWN).

Our population was made of the 7 textile companies operating in the North-West zone of Nigeria as at December, 2008 (See Table 1 below). The whole population was studied using a sample of the 3,250 employees of the companies (Pilot Survey, 2008). Using the Oveson formula (2007) for sample determination, 136 of the 3,250 were purposefully and conveniently sampled to include all senior management staff and all available non-senior management employees.

TABLE 1

LIST OF SEVEN (7) OPERATIONAL TEXTILE COMPANIES IN THE NORTH WEST ZONE OF NIGERIA AS AT DECEMBER, 2008

\begin{tabular}{|l|l|l|}
\hline S/N & COMPANY OF \\
\hline 1 & FUNTUA TEXTILES, FUNTUA & $\begin{array}{l}\text { NO. } \\
\text { UNIONIZED } \\
\text { WORKERS }\end{array}$ \\
\hline 2 & ANGEL SPINNING AND DYEING, KANO & 300 \\
\hline 3 & $\begin{array}{l}\text { NIGERIAN SPINNING AND DYEING (NSD) } \\
\text { Ltd., KANO }\end{array}$ & 500 \\
\hline 4 & LAKHI/JAYKAY CARPET LTD., KANO & 50 \\
\hline 5 & AFRICAN TEXTILE MANUFACTURING LTD., & 1000 \\
\hline
\end{tabular}




\begin{tabular}{|l|l|l|}
\hline & KANO & \\
\hline 6 & CHELLCO INDUSTRIES LTD., KADUNA & 100 \\
\hline 7 & TERYTEX NIGERIA LTD., KANO & 300 \\
\hline & TOTAL & 3250 \\
\hline
\end{tabular}

\section{Source: Field Survey of $30^{\text {th }}$ to $31^{\text {st }}$ December, 2008}

The formula for sample size determination presented by Oveson, (retrieved in 2007), was used to estimate our sample as follows:

$$
n \geq \frac{N \sigma^{2}}{(N-1) D+\sigma^{2}}
$$

$$
D=\frac{(M \arg i n \ldots o f . . e r r o r)^{2}}{Z^{2} \alpha / 2}
$$

Where:

$Z^{2} \alpha / 2=$ The $\mathrm{z}$ value of the normal curve that cuts off the area $\alpha / 2$ at the tail, squared. For our $95 \%$ confidence limit, this is at $97.25 \%$ which $\mathrm{z}$ value is 1.96 .

$\mathrm{n}=$ The Sample Size

$\mathrm{D}=$ The chosen margin of error

$\mathrm{N}=$ The population size

$\sigma^{2}=$ The population variance using a sample variance as an estimate.

Source: Oveson, (2007). Sample Size Determination for Survey Design. Retrieved 05/10/07 from htpp://www.survey.com/client/sampling.doc.

$\sigma^{2}=$ Population variance approximated using the sample variance; our sample variance, from the pilot sample variance was 251.16. This was calculated from the responses to question 2 of the production managers' questionnaires on weaving capacity in appendix II, and the responses to question 16 of the Human Resource on the proportion of decisions taken by individuals. The variance for question 16 of the Human Resource was 251.16 while that of question 2 of the production managers' questionnaires, on weaving capacity, is 21.96. Ten questionnaires were used in computing the variances of both questions 16 and 2. (See Tables $2 \& 3$ below, for the computations of the variances). 
Table 2

Variance for question 2 of Production Managers' questionnaire on Weaving Capacity Utilised

\begin{tabular}{|l|l|l|l|}
\hline S/No. & $\begin{array}{l}\text { \%age of decisions by } \\
\text { individuals (x) }\end{array}$ & $(x-\bar{x})$ & $(x-\bar{x})^{2}$ \\
\hline 1 & 30 & -5.2 & 27.04 \\
\hline 2 & 32 & -3.2 & 10.24 \\
\hline 3 & 36 & 0.8 & 0.64 \\
\hline 4 & 34 & -1.2 & 1.44 \\
\hline 5 & 45 & 9.8 & 96.04 \\
\hline 6 & 28 & -7.2 & 51.84 \\
\hline 7 & 35 & -0.2 & 0.04 \\
\hline 8 & 40 & 4.8 & 23.04 \\
\hline 9 & 38 & 2.8 & 7.84 \\
\hline 10 & 34 & -1.2 & 1.44 \\
\hline Total & 322 & & 219.6 \\
\hline
\end{tabular}

$$
\begin{gathered}
\sigma^{2}=\sum(x-\bar{x})^{2} / \mathrm{n} \\
=219.6 / 10 \\
=21.96
\end{gathered}
$$

Source: Field Pilot Survey of December, 2008.

Table 3

Variance for Question 16 on percentage of decisions taken by individuals.

\begin{tabular}{|l|l|l|l|}
\hline S/No. & $\begin{array}{l}\text { \%age of decisions by } \\
\text { individuals (x) }\end{array}$ & $(x-\bar{x})$ & $(x-\bar{x})^{2}$ \\
\hline 1 & 69 & 14.8 & 219.04 \\
\hline 2 & 32 & -22.2 & 492.84 \\
\hline 3 & 36 & -18.2 & 331.24 \\
\hline 4 & 65 & 10.8 & 116.64 \\
\hline 5 & 68 & 13.8 & 190.44 \\
\hline 6 & 70 & 15.8 & 249.64 \\
\hline 7 & 67 & 12.8 & 163.84 \\
\hline 8 & 63 & 8.8 & 77.44 \\
\hline 9 & 38 & -16.2 & 262.44 \\
\hline 10 & 34 & -20.2 & 408.04 \\
\hline Total & 542 & & 2511.6 \\
\hline
\end{tabular}

Source: Pilot Survey of December, 2008. 


$$
\begin{gathered}
\bar{x}=542 / 10 \\
=54.2 \\
\sigma^{2}=\sum(x-\bar{x})^{2} / n \\
=2511.6 / 10 \\
=251.16
\end{gathered}
$$

We settled for the variance of 251.16 , being the larger variance which sample will also satisfy other questions with smaller variances. An error margin of 5 percent out of our pilot sample shall be allowed. The total responses amounted to 542. Being in percentages, the total shall be the average which is 54.2 (542/10). Our error margin shall, therefore, be $0.05 * 54.2$ which is equal to 2.71

Substituting our variables into the Oveson (2007) formula, we had:

$$
\begin{aligned}
\mathrm{D}= & \frac{2.71^{2}}{1.96^{2}} \\
& =7.34 / 3.84 \\
& =1.91
\end{aligned}
$$

Therefore,

$$
\mathrm{n} \quad \geq \frac{3250(251.2)}{[(3250-1) 1.91+251.2]}
$$

$\geq \frac{816400}{6457}$

$$
\geq 126 \text {. }
$$

Our sample of staff of the seven companies that filled our questionnaires was made up of 126 employees.

\section{Findings and Discussions}

The textile companies examined showed a 30 percent decline in capacity utilisation from 1990 to 2008. This is consistent with data obtained from the Central Bank of Nigeria and the Federal Office of Statistics. Onipe (2001) had earlier found 8 manufacturing companies, 2 of which were textile companies to be embarking on retrenchment strategy by which the companies prolonged the use of their machineries instead of replacing them, producing to order instead of aggressive marketing, cutting down on personnel cost instead of innovatively engaging their workforce or even increasing their staff strength. Morrow, Sirmon, Hitt, and Holcomb (2007) found that using existing resources (human resources) in new ways enhances the recovery of organizations. Further more, Chan (2005) had shown that firm size had a moderating influence on performance by enabling an organization to 
develop General Operating Capability.

All the textile companies studied started operation in the early 1980s with only one said to have carried out partial replacement of machineries. This confirms Jibrin's (2002) claim of the companies' inability to have new technology comparable to competitors in China. Machine capacity is a valuable resource that is firm specific because it has transaction and transfer cost and usually involves chameleon-like know-how (Tieece, Pisano, and Shuen, 1997). For these reasons, the possession of new machineries with the associated technological know-how can procure sustainable competitive advantage for a firm (Black and Boal, 1994).

Only one out of the seven textile companies studied showed Human Resources Management emphasis above goal emphasis. This was indicated by priority ranking of goals such as Employee Satisfaction, Employee wellbeing, and Cordial employee relations. All the other six companies showed Goal Emphasis captured by priority ranking of goals such as Objective achievement, Meeting of deadlines, and Execution of Assignment. This agrees with the findings of Hansen and Wernerfelt (1989) that both Goal emphasis and Human Resources Management emphasis are performance determinants with the Human Resources Management emphasis accounting for twice as much performance as the Goal Emphasis. Less emphasis being placed on human resources management is in line with Onipe's (2001) findings of some of the textile companies retrenching staff instead of innovatively deploying them.

\section{PRESENTATION AND ANALYSES OF RESULTS}

\section{TABLE 4}

STATISTICS OF ELECTRICITY CONSUMPTION AND AVERAGE CAPACITY UTILISATION OF TEXTILE COMPANIES

\begin{tabular}{|l|l|l|}
\hline Year & $\begin{array}{l}\text { \% of total electricity consumption to } \\
\text { Industries in megawatts per hour } \\
\text { (Independent Variable) }\end{array}$ & $\begin{array}{l}\text { Average manufacturing } \\
\text { utilisation rates of textile Companies } \\
\text { (Dependent Variable) }\end{array}$ \\
\hline 1989 & 26.4 & 59.7 \\
\hline 1990 & 25.6 & 52.2 \\
\hline 1991 & 25.6 & 54.9 \\
\hline 1992 & 24.7 & 44.3 \\
\hline 1994 & 21.3 & 38.2 \\
\hline 1996 & 22.8 & 46.5 \\
\hline 1997 & 23.5 & 50 \\
\hline 1999 & 21.7 & 20.2 \\
\hline 2000 & 22.0 & 21.4 \\
\hline 2001 & 21.9 & 31.8 \\
\hline 2006 & 21 & 56 \\
\hline 2007 & 22 & 41 \\
\hline 2008 & 20 & 39 \\
\hline
\end{tabular}

Source: Central Bank of Nigeria, Statistical Bulletin, Volume 18, December 2007 and CBN 
Annual Reports, December 2008 \& December 2009.

CORRELATIONS

/VARIABLES=VAR00001 VAR00002

/PRINT=TWOTAIL NOSIG

/MISSING=PAIRWISE .

\section{Correlations}

\begin{tabular}{|c|c|c|c|}
\hline & & $\begin{array}{l}\text { VAR000 } \\
01\end{array}$ & $\begin{array}{l}\text { VAR000 } \\
02\end{array}$ \\
\hline \multirow{3}{*}{$\begin{array}{l}\text { VAR000 } \\
01\end{array}$} & Pearson & 1 & $.578(*)$ \\
\hline & $\begin{array}{l}\text { Correlation } \\
\text { Sig. (2-tailed) }\end{array}$ & & .030 \\
\hline & $\mathbf{N}$ & 14 & 14 \\
\hline \multirow{3}{*}{$\begin{array}{l}\text { VAR000 } \\
02\end{array}$} & Pearson & $.578(*)$ & 1 \\
\hline & Sig. (2-tailed) & .030 & \\
\hline & $\mathbf{N}$ & 14 & 14 \\
\hline
\end{tabular}

* Correlation is significant at the 0.05 level (2-tailed).

Source: Correlation analysis using SPSS 15.0

\section{DISCUSSION OF RESULTS}

The results of the analyses above show a correlation coefficient of 0.578 , indicating a strong positive correlation between the resource factor of public electricity supply and the capacity utilisation of the textile companies studied. The result is also significant at $95 \%$ confidence level. This suggests some connection between the dwindling electricity supply to the textile companies and their performance, judging by their capacity utilisation, other factors held constant. By deduction, the performance of the textile companies could be improved by increasing the public electricity supply going to them, among other issues.

When we square the Pearson correlation coefficient of $\mathrm{r}=0.578$, we get $\quad r^{2}=0.334$.

$$
r^{2}=\frac{\text { Total Variation-unexplained Variation }}{\text { Total Variation }}
$$

This means that we can achieve $33.40 \%$ reduction in error when we use public electricity supply to predict the performance of the textile companies using capacity utilisation as a proxy for performance. This also means that $33.40 \%$ of the variance in capacity utilisation is caused by variation in public electricity supply.

These results are consistent with other findings (Hansen and Wernerfelt, 1989; Onipe, 
2001; and Chan, 2005) that showed economic and organisational factors impinging on firm performance. Strategic management factors have greater influence on performance since they constitute the combinative mechanism through which the economic factors are engaged to yield value to the organization.

\section{Conclusion And Recommendation}

Electricity supply to the textile companies is a critical resource factor. Our analysis show that there are other resource factors involved in the performance of the textile Companies. This means that the efforts by the Goodluck Jonathan administration to provide funds at one-digit interest rate are steps in the right direction. This, however, should be followed up with a repositioning of the electricity generation and distribution sector.

Efforts should be made to see that all industrial areas have dedicated power lines that are supplied with electricity 24 hours a day. A presidential task force should be established and charged with the responsibility of doing this. The ministers of Power and industry, State Commissioners of industry and the Chairman of Manufactures' Association of Nigeria should be members. This will go a long way in reducing production cost that will enable local manufacturers charge competitive prices. The situation now is that companies operate mostly on generators powered with diesel oil which is very expensive. This, in turn, leads to higher production cost, higher unit cost and less than competitive product prices.

Advocacy on the pride in using locally made goods, beginning with Nigerian fabrics, should be done by the National Orientation Agency and the Ministry of Information and Communication. This should be carried out at Federal, State and Local Government levels. Advocacy should be backed up with 'Leadership by example'. Leaders should patronize and be seen to use locally made goods. In this regards, the efforts of the former civilian President, Olusegun Obasanjo, appearing in locally made fabrics on official functions are commended. 


\section{References}

Abubakar, A. T. The Marketing Problem of Textile Industries in Nigeria: A Case Study of United Nigeria Textile PLC, MBA Thesis, Ahmadu Bello University Zaria, 1997.

Adebisi, O. O. The Impact of Import Regulation on the Textile Manufacturing Industry in Nigeria, MBA Thesis University of Jos, 1987.

Ahiuma-Young, V. (2003). The Sun will shine again for the Textile Industry if. http://www.nlcng.org/Press/vanguardmarch26032004.htm Retrieved 27/07/07

Aremu, I. O. Collapse of the Textile Industry in Nigeria: Implications for Employment and Poverty Eradication. A Project to National Institute for Policy and Strategic Studies (NIPSS), Kuru, 2005.

Ati,R.I. Perceiving the Environment: Its Relationship with Values and Cognitive Process: An Empirical Study of Nigerian Managers, M.Sc Thesis Psychology, University of Jos, 1985.

Ayodele (1998). Energy Crisis in Nigeria: The case of Electricity Energy Market. The Bullion, CBN, 22(4):19-24

Black, J.A. and Boal, K.B. (1994). Strategic Resources: Traits, Configurations and Paths to Sustainable Competitive Advantage. Strategic Management Journal Special Issue 15:131-148.

Chan, R.Y.K. (2005). Does the Natural-Resource-Based-View of the firm apply in an emerging Economy? A survey of foreign invested enterprises in China. Journal of management studies 42(3)625-672.

Central Bank of Nigeria (1996). Annual Report and Statement of accounts, $31^{\text {st }}$ December, 1996.

Central Bank of Nigeria (2000). Annual Report and Statement of accounts, $31^{\text {st }}$ December, 2000.

Central Bank of Nigeria (2007). Annual Report and Statement of accounts, $31^{\text {st }}$ December, 2007.

Central Bank of Nigeria (2008). Annual Report and Statement of accounts, $31^{\text {st }}$ December, 2008.

Central Bank of Nigeria (2007). Statistical Bulletin, Vol.18

David, A. M and Rothschild, J (2003). Nigeria Cotton and Products Annual 2003, USDA Foreign Agricultural Service, GAIN Report.

Fanimo, D., Sanyaolu, A. and Akhaine, S. UNTL closure: Fresh assault on human capital. The Guardian Newspapers (Lagos), 16 October, 2007 p.37.

Hansen, G.S. and Wernerfelt, B. (1989). Determinants of Firm Performance: The relative Importance of Economic and Organizational Factors. Strategic management 
Journal 10 (5): 399-411 (Electronic Version).

Jibrin, W. Situation Report on The Nigerian Textile Industry and the Way forward: A brief presentation. Unpublished paper Presented at a Seminar organised by The National Union of Textiles, Garment and Tailoring Workers of Nigeria, $24^{\text {th }}$ May, 2002.

Mohammed, H.T. Kaduna Textiles Mills Limited (KTL) Management of the Marketing Function: A Case Study, MBA Thesis Ahmadu Bello University Zaria. 1984

Morrow Jr, J. L, Sirmon, D. G., Hitt, M. A., and Holcomb, T. R. (2007). Creating Value in the Face of Declining Performance. Strategic Management Journal, 28 (3): 243-270, Willey Inter Science

Onipe, E. O. Determinants of Strategic Choice for Nigerian Enterprises, 1980-1988. Ph.D. Thesis, Ahmadu Bello University, Zaria, 2001

Teece, D.J., Pisano G., and Shuen, A. (1997). Dynamic capabilities and Strategic Management, Strategic Management Journal 18 (7): 509-533, (Electronic Version).

Ubani, C. A. Organizations Environment: An Empirical Survey of Environmental Factors and Dimensions of Uncertainty Affecting Nigerian Organizations, M. Sc Thesis (Psychology), University of Jos, 1983.

Uzoigwe, S. (2005). Review of the Nigerian Textile Industry, International Bank Plc. Retrieved $10^{\text {th }}$ January, 2007 from: http://www.intercontinentalplc.com

World Bank (1991). World Bank Development Reports 